\title{
Fold-to-Fault Progression of a Major Thrust Zone Revealed in Horses of the North Mountain Fault Zone, Virginia and West Virginia, USA
}

\author{
Randall C. Orndorff \\ U.S. Geological Survey, 926A National Center, Reston, VA 20192, USA \\ Correspondence should be addressed to Randall C. Orndorff, rorndorf@usgs.gov
}

Received 14 March 2012; Accepted 22 May 2012

Academic Editor: David T. A. Symons

Copyright ( 2012 Randall C. Orndorff. This is an open access article distributed under the Creative Commons Attribution License, which permits unrestricted use, distribution, and reproduction in any medium, provided the original work is properly cited.

\begin{abstract}
The method of emplacement and sequential deformation of major thrust zones may be deciphered by detailed geologic mapping of these important structures. Thrust fault zones may have added complexity when horse blocks are contained within them. However, these horses can be an important indicator of the fault development holding information on fault-propagation folding or fold-tofault progression. The North Mountain fault zone of the Central Appalachians, USA, was studied in order to better understand the relationships of horse blocks to hanging wall and footwall structures. The North Mountain fault zone in northwestern Virginia and eastern panhandle of West Virginia is the Late Mississippian to Permian Alleghanian structure that developed after regionalscale folding. Evidence for this deformation sequence is a consistent progression of right-side up to overturned strata in horses within the fault zone. Rocks on the southeast side (hinterland) of the zone are almost exclusively right-side up, whereas rocks on the northwest side (foreland) of the zone are almost exclusively overturned. This suggests that the fault zone developed along the overturned southeast limb of a syncline to the northwest and the adjacent upright limb of a faulted anticline to the southeast.
\end{abstract}

\section{Introduction}

The North Mountain fault is a major structure that extends about $150 \mathrm{mi}(240 \mathrm{~km})$ from Rockbridge Co., central Virginia, northward to south-central Pennsylvania in the eastern U.S. Along the fault, Cambrian and Ordovician dominantly carbonate rocks occur in the hanging wall at the present erosion level and Silurian and Devonian clastic rocks occur in the footwall. The fault is a zone, which is as much as 1mile wide, that contains rocks from Cambrian to Devonian age in a series of fault slices or horses. In the study area, the present leading edge lies on a footwall frontal ramp that rises from a lower décollement in Cambrian rocks. To the south, the North Mountain fault loses displacement in Rockbridge Co., where horizontal shortening is transferred to the Staunton-Pulaski thrust system located to the southeast [1].
Rader and Perry Jr. [2], Kulander and Dean [1, 3], and Dean et al. [4] interpreted fault genesis to a faultpropagation fold. In this model, the overturned limb of the fault-propagation fold is preserved in the footwall and total displacement is less than $10 \mathrm{mi}(16 \mathrm{~km})$. An alternative interpretation [5] based on seismic reflection data describes the North Mountain fault as the leading edge of a large thrustsheet complex that duplicates Cambrian and Ordovician rocks in the Great Valley. Evans [5] estimated more than $35 \mathrm{mi}(56 \mathrm{~km})$ of displacement.

The North Mountain thrust sheet occupies an area between the Blue Ridge Mountains on the east and the Valley and Ridge province on the west. This area of the Central Appalachians is physiographically defined by the Great Valley or Shenandoah Valley (Figure 1). The thrust sheet is composed of approximately 10,000 ft (3,050 m) of Cambrian and Ordovician carbonate rocks. Within the eastern portion of 

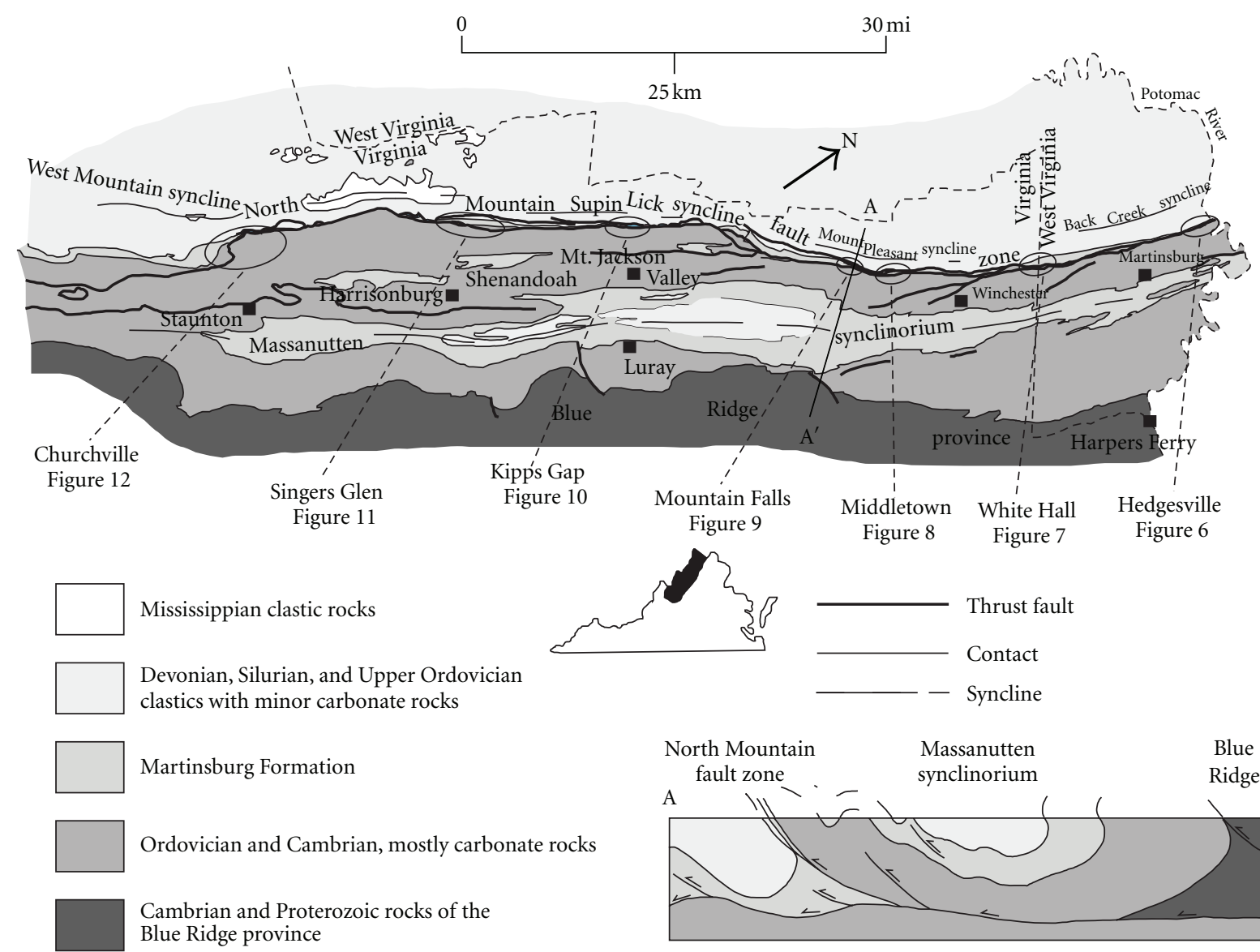

Martinsburg Formation

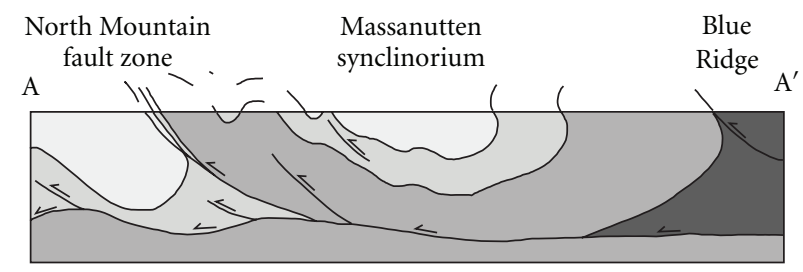

Figure 1: Generalized geologic map and cross section of part of the Central Appalachians showing the North Mountain fault zone and areas of detailed geologic mapping.

the North Mountain thrust sheet, Paleozoic carbonate rocks are typically steeply dipping and overturned. Within the western portion of the thrust sheet, the Paleozoic carbonate rocks are typically right-side up and southeast dipping. The major structure on the North Mountain thrust sheet is the doubly plunging Massanutten synclinorium, which extends from central Virginia to south-central Pennsylvania (Figure 1). Just west of the leading edge of the thrust sheet, a discontinuous ridge (Little North Mountain) is composed of the Silurian Tuscarora Quartzite. In places where the Tuscarora does not occur as isolated horses or as a continuous stratigraphic horizon on the footwall syncline, a ridge is not present (Figure 2).

Giles [6] was the first to recognize and describe a thrust fault along Little North Mountain in northern Virginia. $\mathrm{He}$ described the feature as a discontinuity between the Cambrian Elbrook Formation and the overturned and overridden Ordovician Martinsburg Formation. Butts and Edmundson [7] found little evidence of complex faulting. They suggested that thinning of stratigraphic units was due to depositional processes. Later, Butts and Edmundson [8] interpreted the rocks near North Mountain as a continuous sequence of previously unrecognized unconformities cut by a single fault. These early workers did not recognize the Ordovician rocks exposed as horses within the fault zone.
Their mapping showed the Elbrook Formation occurs in the hanging wall and rocks of the Martinsburg Formation and Tuscarora Quartzite occur in the footwall.

\section{Lithotectonic Units}

Rocks of the Valley and Ridge province of the North Mountain thrust sheet and the footwall of the thrust sheet in northern Virginia and West Virginia can be divided into three lithotectonic units bounded by detachments (Figure 3 ). The lower unit is comprised of the Middle Cambrian Elbrook Formation through the Middle Ordovician Edinburg Limestone (or Chambersburg Limestone in the West Virginia Panhandle). This unit is dominantly carbonate rock with medium- to thick-bedded dolomite and limestone in the lower part and thinner bedded carbonate rocks in the upper part. Structurally, large-amplitude folds occur in the basal part of the section and tighter folds occur in the upper part of the section.

The middle lithotectonic unit is comprised of shale, siltstone, sandstone, and shaly limestone of the Middle and Upper Ordovician Martinsburg Formation. This unit is $5,000 \mathrm{ft}(1,524 \mathrm{~m})$ thick and is complexly folded, faulted, and cleaved. The Martinsburg is exposed in the Massanutten synclinorium and within the North Mountain fault zone. 


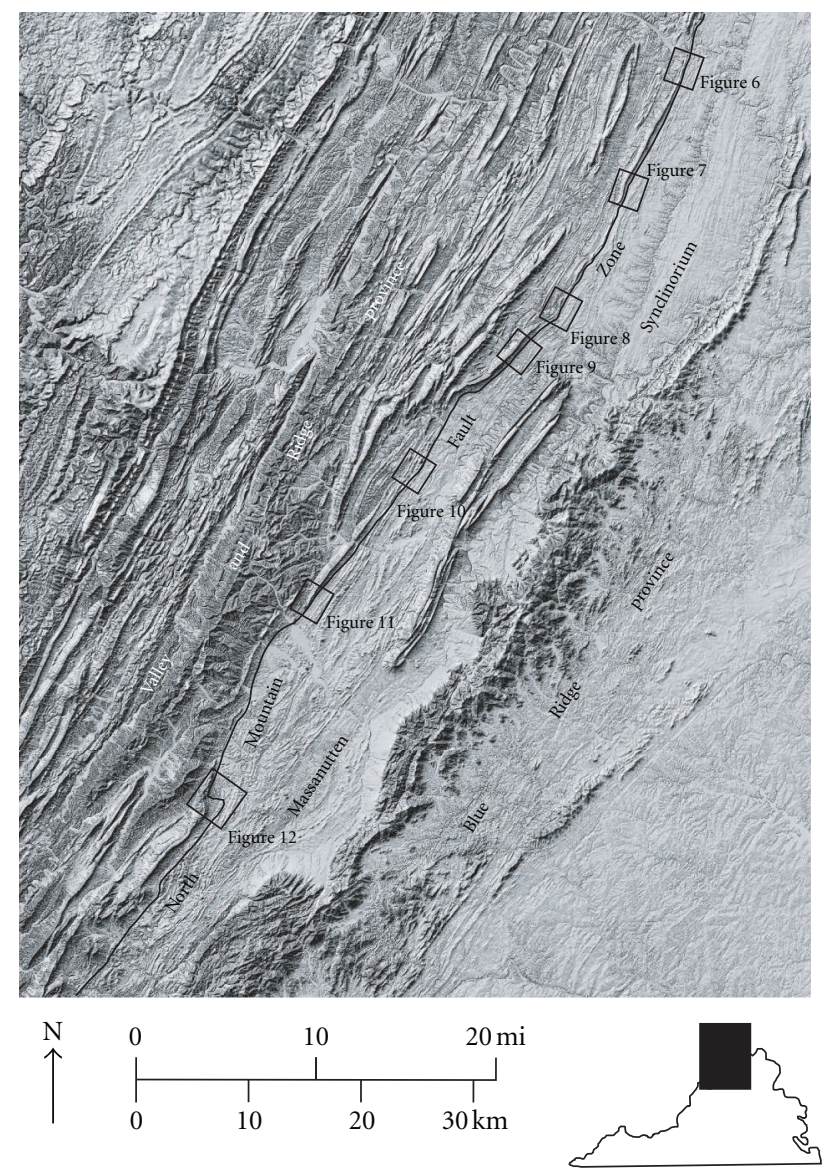

Figure 2: Digital elevation model (developed from U.S. Geological Survey National Elevation Dataset; http://ned.usgs.gov/) of part of the Central Appalachians showing the North Mountain fault zone and Massanutten synclinorium.

The upper lithotectonic unit consists of dominantly clastic rocks of the uppermost Ordovician through Devonian. These rocks are the youngest exposed in the Massanutten synclinorium and are also the footwall of the North Mountain fault zone. Evans [5] discussed the lithotectonic units in terms of competent and incompetent units, where incompetent units are detachments. In these terms, the lower lithotectonic unit is bounded by the Waynesboro Formation or Waynesboro detachment at the base and the Martinsburg detachment or middle lithotectonic unit above.

\section{Detailed Geology along the North Mountain Fault Zone}

Detailed geologic mapping holds the key to understanding the development of the North Mountain fault zone (Figure 4). 1:24,000-scale geologic mapping along the fault shows the typical map patterns and fault geometry of horses along a 70-mile (113-km) stretch from central Virginia to the eastern West Virginia panhandle (Figure 1).

In the areas mapped, the hanging wall of the North Mountain fault zone consists of southeast-dipping Cambrian

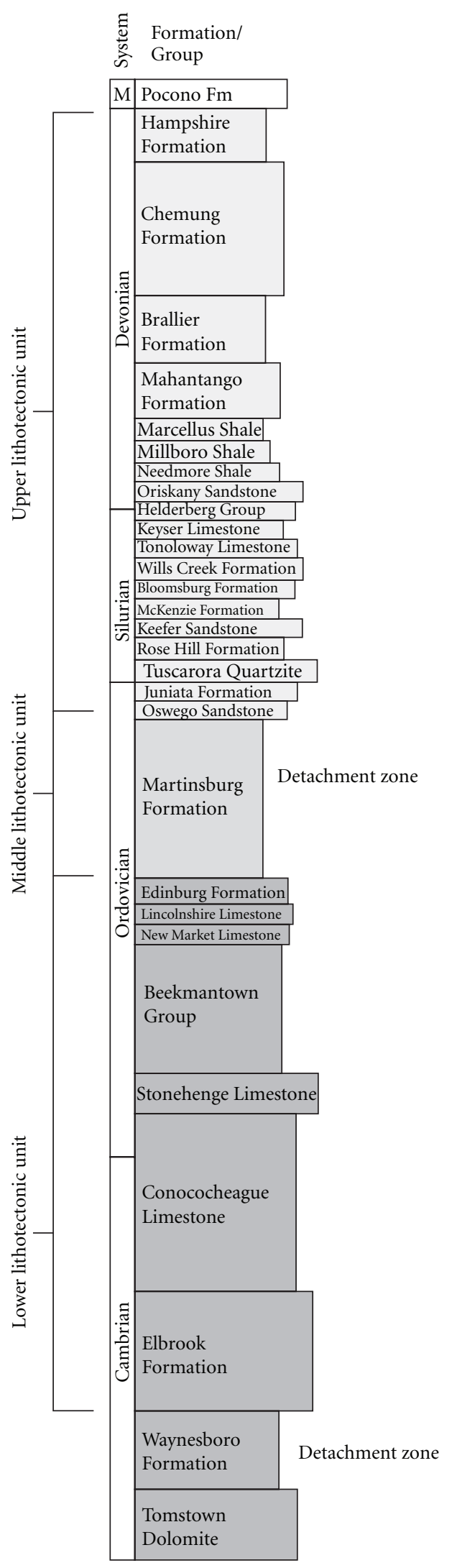

FIGURE 3: Stratigraphic column of geologic units exposed in the Great Valley and Valley and Ridge provinces showing lithotectonic units and detachment zones. Thicknesses are relative and not to scale. Modified from [5]. 


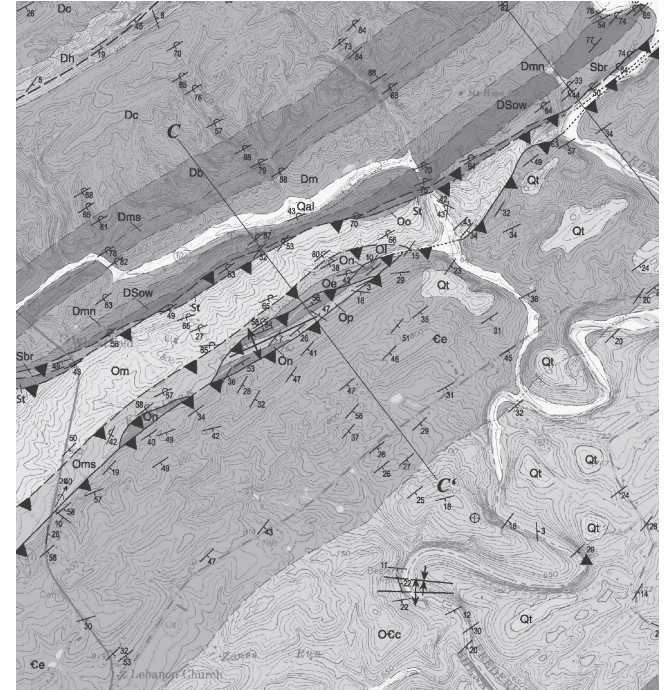

Figure 4: Section of the Middletown, Virginia, 7-1/2 minute geologic map [13] showing typical $1: 24,000$-scale geologic mapping used for this study. Figures 6-12 are from, or modified from, geologic maps at this scale.

Elbrook Formation rocks on the upright western limb of the Massanutten synclinorium (Figures 5-12). Although subsidiary folds occur on the western limb of the synclinorium, the beds along the fault zone consistently dip southeast. In the footwall of the North Mountain fault zone is a series of overturned synclines. In the Hedgesville quadrangle, Berkeley County, West Virginia (Figure 6), the fault zone consists of a series of upright anticlines and synclines that make up smaller 2nd-order folds on the west limb of the Massanutten synclinorium. The footwall is the overturned Back Creek syncline [9]. To the south in the White Hall quadrangle, Frederick County, Virginia (Figure 7), the hanging wall is made up of an anticline-syncline pair of the Welltown syncline and Pumpkin Ridge anticline, and the footwall is the overturned Mount Pleasant syncline composed of Devonian Mahantango Formation [10, 11]. The overturned Mount Pleasant syncline also occurs in the footwall in the Middletown and Mountain Falls quadrangles, Frederick and Shenandoah Counties, Virginia (Figures 8 and 9). Footwall structures are well exposed at Baldwin Gap in the Middletown quadrangle. There, Silurian and Devonian rocks of the overturned eastern limb of the Mount Pleasant syncline are exposed [12]. The geologic formations are thinner than in typical outcrop belts to the west in the Valley and Ridge province. Beddingparallel décollements and several splays also occur. These faults are reverse faults with southeastward displacement. At Kipps Gap in Shenandoah County, Virginia, the footwall consists of overturned southeast-dipping Marcellus Shale of the Supin Lick syncline (Figure 10). The footwall in the Singers Glen quadrangle, Rockingham County, Virginia exposes Devonian shale as the overturned limb of the West Mountain syncline (Figure 11) that also makes up the footwall in the Churchville quadrangle, Augusta County, Virginia (Figure 12).
3.1. Geology of Horses within the Fault Zone. Between the hanging wall of the North Mountain fault zone and footwall synclines many horses occur. Although these horses have moved within the fault zone, the orientation of bedding remains consistent with Central Appalachian trends of about $\mathrm{N} 30^{\circ}-40^{\circ} \mathrm{E}$. The fault zone ranges from $1 / 4-$ mile (0.4-km) wide across strike in the Hedgesville quadrangle, West Virginia (Figure 6) to $1 / 2$-mile $(0.8-\mathrm{km})$ wide in the Middletown quadrangle, Virginia (Figure 8) to 1-mile (1.6$\mathrm{km}$ ), in the Singers Glen quadrangle, Virginia (Figure 11). However, the number of exposed horses across the fault zone varies between one (Figures 7 and 12) and six (Figure 11) along this 70 -mile stretch $(113-\mathrm{km})$. For much of the length of the fault, multiple horses are stacked within the fault zone.

Along the entire trace of the fault zone, rocks in horses of the east side of the zone (hinterland) are right-side up and rocks on the west side (foreland) are almost exclusively overturned. In the Hedgesville quadrangle, the only rightside up rocks in horses in this stretch of the North Mountain fault zone are from the Beekmantown Group. The horses westward in the zone are made up of overturned rocks of the upper part of the Chambersburg Limestone (equivalent to the upper part of the Edinburg Formation in Virginia) and the lowermost rocks of the Martinsburg Formation. Thin horses of overturned Juniata Formation and Tuscarora Quartzite occur westward throughout the fault zone and form linear ridges.

In the White Hall quadrangle along the Virginia-West Virginia border, the largest horse in the fault zone is a steep north-plunging, upright anticline cored by the Rockdale Run Formation. This horse is thrust on a smaller horse of eastdipping, right-side up Pinesburg Station Dolomite through Chambersburg Limestone. Although the west side of the fault zone thrusts overturned Ordovician Martinsburg Formation over Upper Ordovician, Silurian, and Devonian rocks in the footwall, it appears that the fault dies out to the north where there is continuous exposure of Martinsburg through Lower Devonian Oriskany Sandstone [10].

The North Mountain fault zone in the Middletown quadrangle consists of many horses of older rock units over younger rock units [13]. The change from right-side up to overturned beds occurs within the uppermost part of the Edinburg Formation (equivalent to the upper part of the Chambersburg Limestone in West Virginia) and the lowest part of the highly deformed Martinsburg Formation. As many as nine horses of various Ordovician and Silurian units, with as many as five across strike, occur in the $1 / 2$ mile $(0.8-\mathrm{km})$ wide fault zone in this area (Figure 8$)$. One horse is an upright anticline cored by Beekmantown Group. Another fault is recognized by the thin exposure of the Martinsburg Formation where the lowermost member, the Stickley Run Member, is thrust over uppermost Martinsburg and the Oswego Sandstone. The Martinsburg in this area of the Central Appalachians has been reported as much as $6,500 \mathrm{ft}(1,981 \mathrm{~m})$ thick [14], and the outcrop thickness along the North Mountain fault is less than 1,500 ft (457 m). Horses of the resistant Silurian Tuscarora Quartzite make up ridges along the fault zone west of the Martinsburg Formation exposures. 


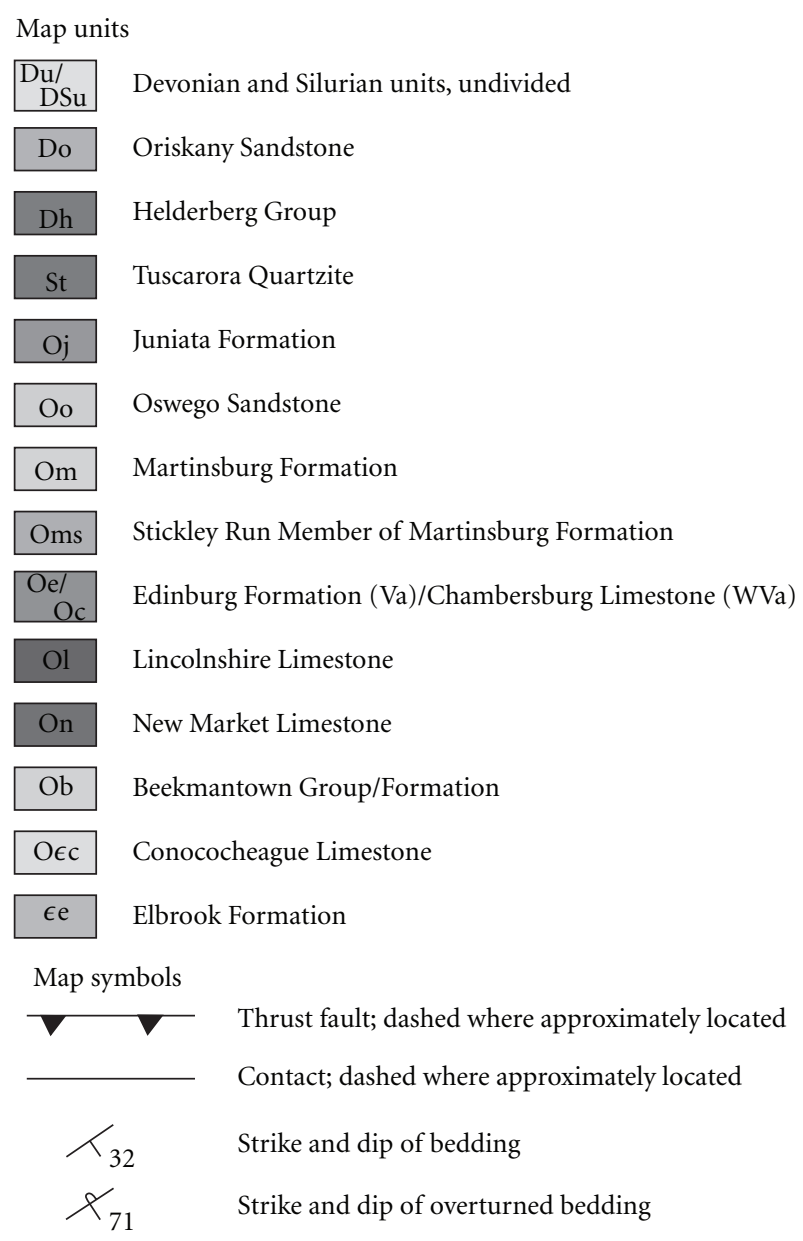

FIGURE 5: Map units and map symbols used in Figures 6-12.

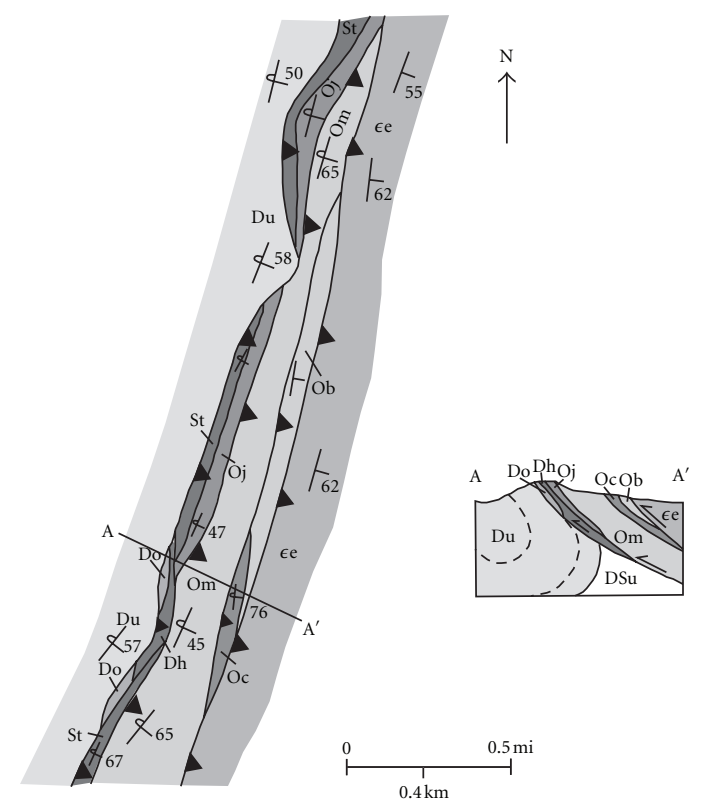

FIgURE 6: Geologic map of the North Mountain fault zone in the Hedgesville quadrangle, Berkeley County, West Virginia, modified from [9]. 


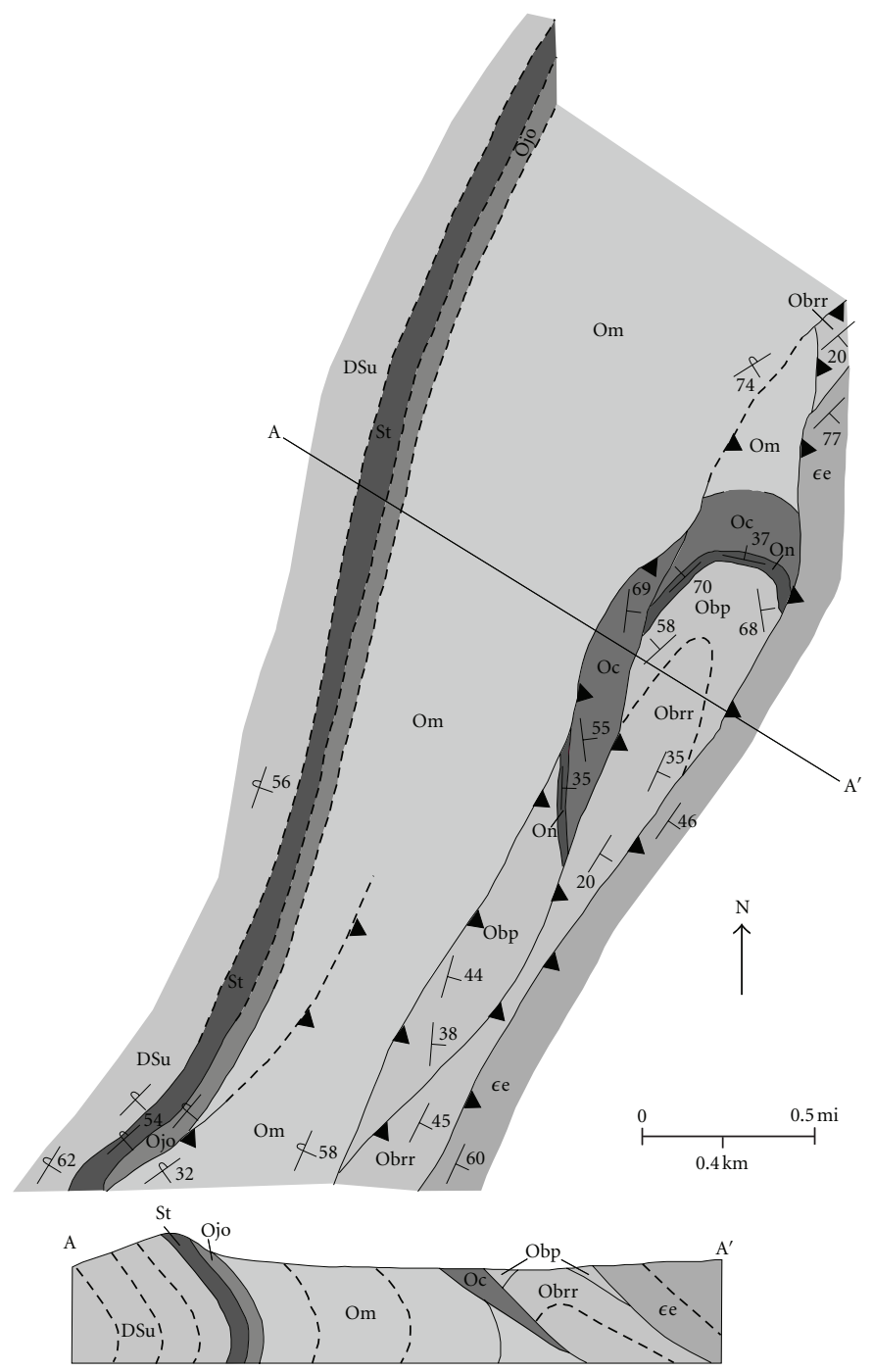

Figure 7: Geologic map of the North Mountain fault zone in the White Hall quadrangle, Frederick County, Virginia, modified from [10]. Obrr: Rockdale Run Formation of the Beekmantown Group; Obps: Pinesburg Station Dolomite of the Beekmantown Group.

Horses of Cambrian and Lower Ordovician units in the Mountain Falls quadrangle are thin, but still show the same relationships as those in other areas along the fault zone (Figure 9). Various horses mapped by McDowell [15] consist of right-side up Upper Cambrian and Lower Ordovician Conococheague Limestone, right-side up Middle Ordovician Beekmantown Formation (equivalent to the Rockdale Run Formation to the north), right-side up Middle Ordovician New Market and Lincolnshire Limestones, and overturned Stickley Run Member of the Martinsburg Formation. The west side of the fault zone consists of two linear, large horse blocks. One of these blocks consists of overturned beds of the upper part of the Martinsburg Formation and Oswego Sandstone, and the other overturned sandstone of the Tuscarora Quartzite.

In Kipps Gap in Shenandoah County, Virginia (Timberville and Orkney Springs quadrangles), various Cambrian through Devonian units occur as horses along the North Mountain fault zone (Figure 10). A quarry on the east side of the fault zone exposes highly fractured limestone and dolostone of the Beekmantown Formation with shallowdipping New Market Limestone just to the west delineating a west-dipping limb of a decapitated anticline. Westward, thin horses of the overturned Edinburg Formation and the Stickley Run Member of the Martinsburg Formation are thrust on upper units of the Martinsburg Formation that are thrust on Tuscarora Quartzite and limestone of the Silurian and Devonian Helderberg Group. The westernmost fault places the Tuscarora and Helderberg onto the Devonian Marcellus Shale, which makes up the eastern limb of the overturned Supin Lick syncline.

Horses along the North Mountain fault zone in the Singers Glen quadrangle, Rockingham County, Virginia, tend to be long and thin (Figure 11). Brent [16] mapped the various upright Ordovician units along Little North Mountain; however, they contain a reversed stacking order without faulting. Orndorff [17] recognized seven horses across a nearly 1 -mile $(1.6-\mathrm{km})$ wide section of the North 


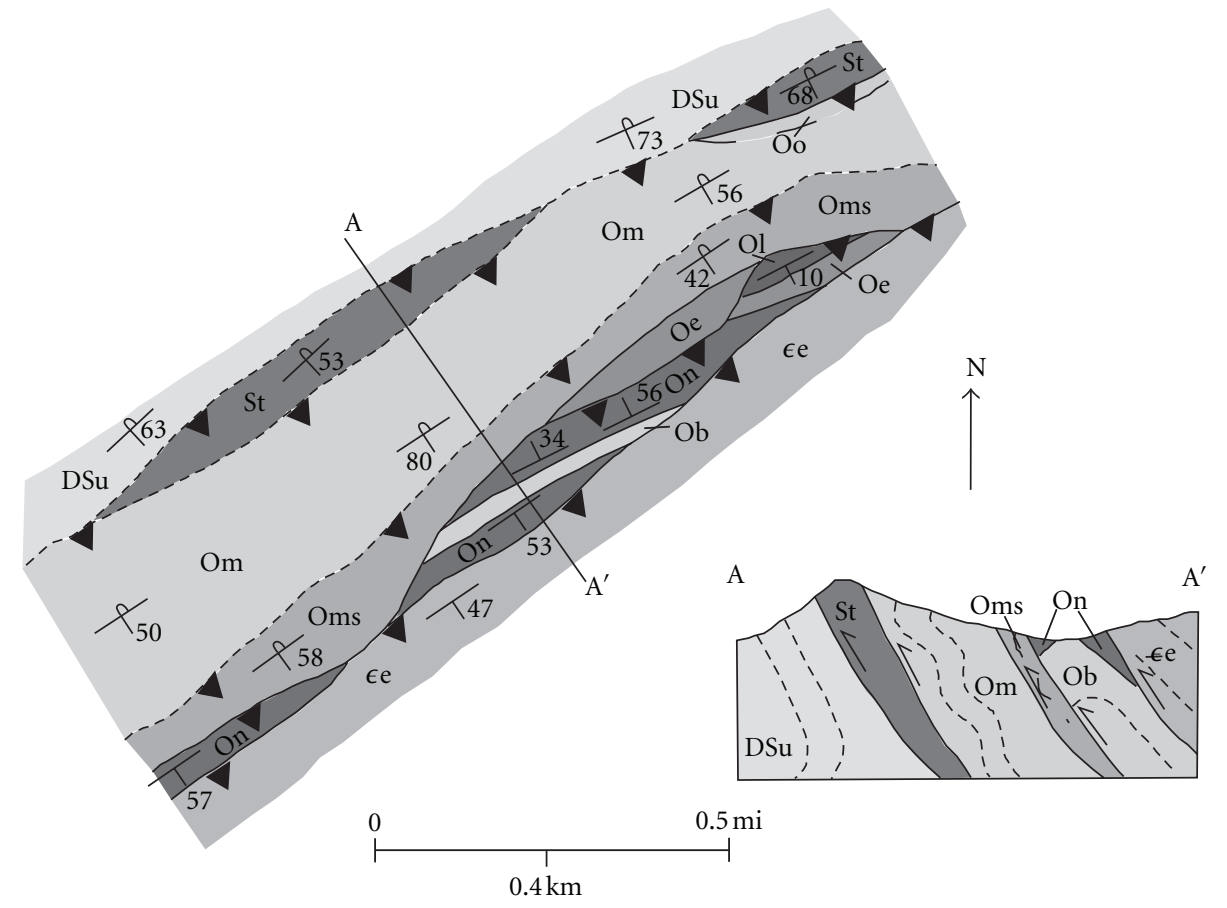

Figure 8: Geologic map of the North Mountain fault zone in the Middletown quadrangle, Shenandoah County, Virginia, from [13].

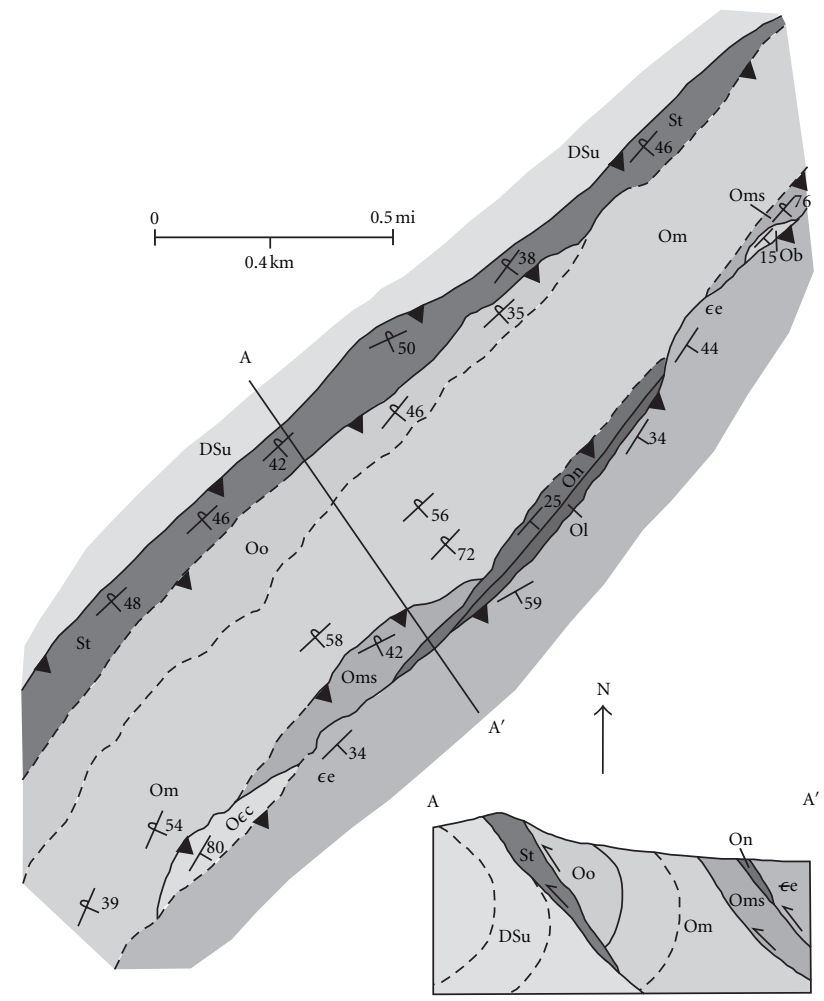

Figure 9: Geologic map of the North Mountain fault zone in the Mountain Falls quadrangle, Shenandoah County, Virginia, modified from [15]. 


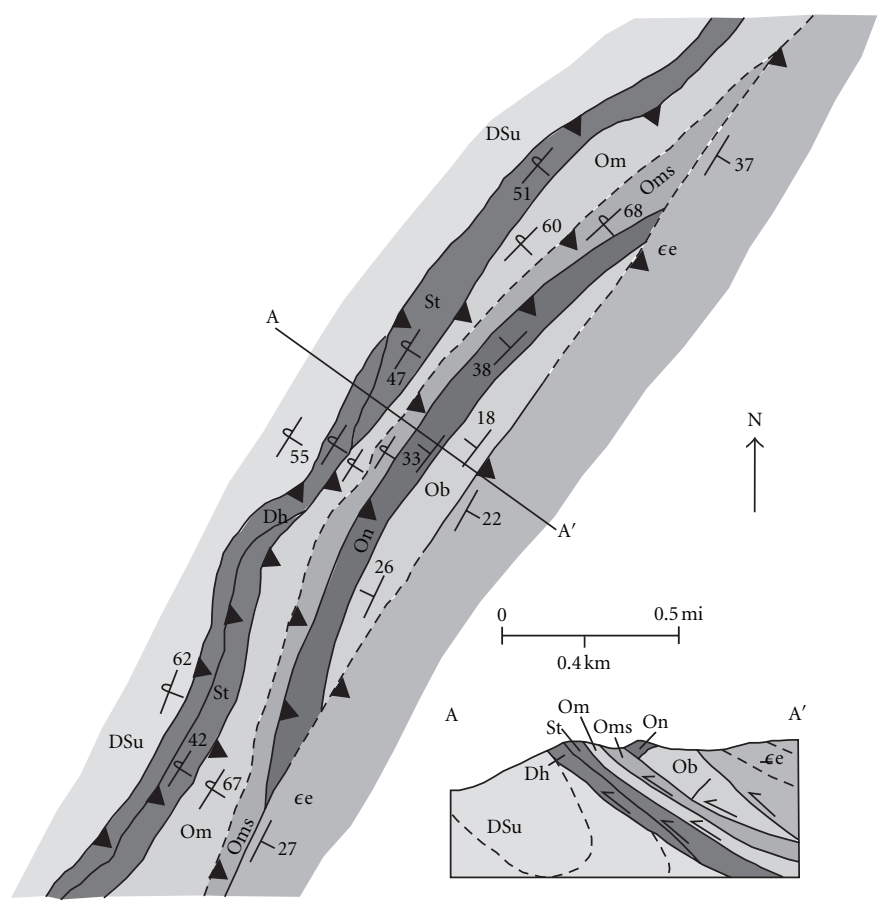

FIgURE 10: Geologic map of the North Mountain fault zone in the Kipps Gap area, Shenandoah County, Virginia (unpublished mapping by author).

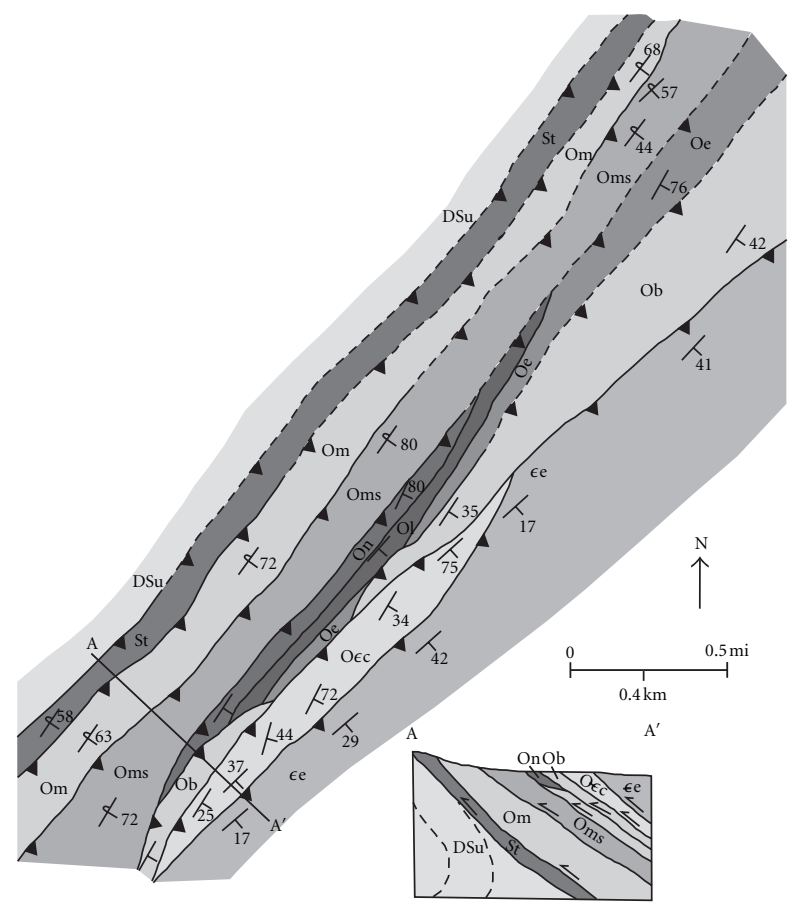

FIgURE 11: Geologic map of the North Mountain fault zone in the Singers Glen quadrangle, Rockingham County Virginia, from [17].

Mountain fault zone, which explained the order of the units mapped by Brent and their upright and overturned nature. Horses of right-side up stratigraphic units in the east part of the fault zone include the Upper Cambrian and Lower Ordovician Conococheague Limestone, two horses of Lower and Middle Ordovician Beekmantown Formation, and one with a section of Middle Ordovician New Market Limestone through Edinburg Formation. The first horse exposing overturned strata contains the Stickley Run Member of the Martinsburg Formation. This is continued southwestward 


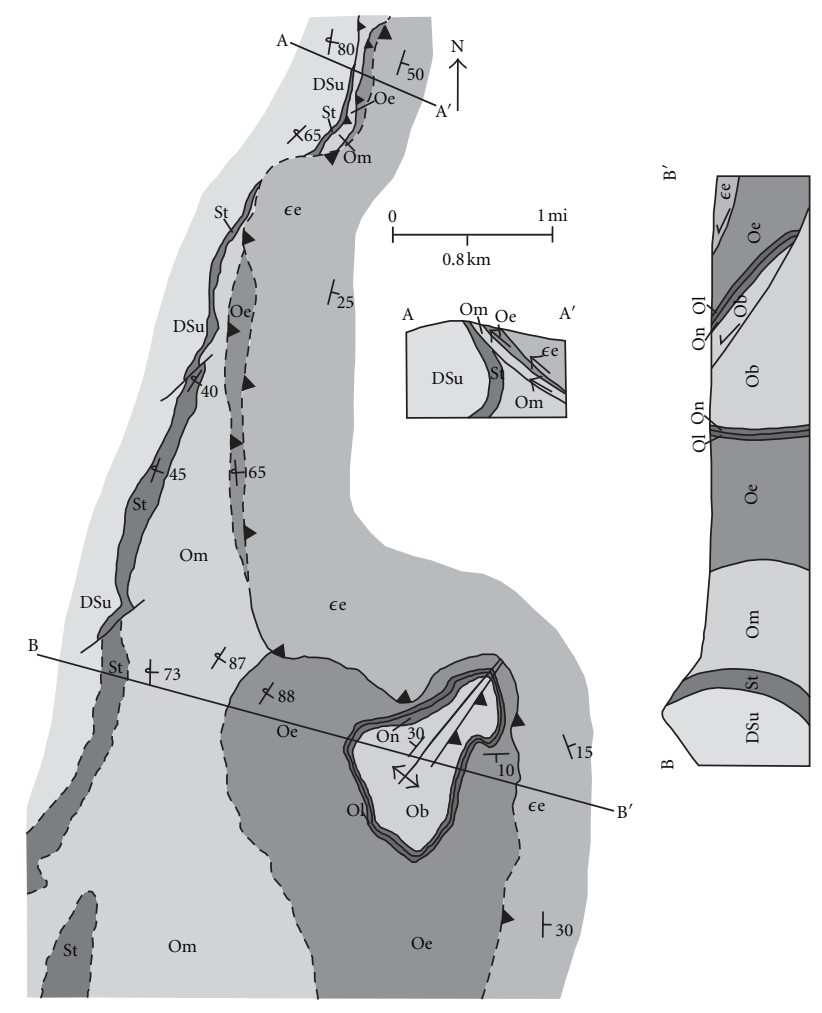

FIGURE 12: Geologic map of the North Mountain fault zone in the Churchville quadrangle, Augusta County, Virginia, modified from [19].

with horses of the upper part of the Martinsburg Formation and the Tuscarora Quartzite that is topographically expressed as Little North Mountain.

3.2. Change in Fault Zone Characteristics. In the Churchville quadrangle in Augusta County, Virginia, a major change in the characteristics of the North Mountain fault zone occurs. Displacement decreases and shortening of the StauntonPulaski fault system increases [1]. Just to the south of this area, the Pulaski fault becomes the predominant thrust system [18], and there is a transition zone in Augusta County. Geologic mapping by Rader [19] reveals flattening of the North Mountain fault and exposes an anticline of Middle Ordovician rocks in the footwall (Figure 12). North of this southeastward trend of the fault, the North Mountain fault zone is consistent with mapped areas to the north where rocks in the hanging wall are right-side up with lower Middle Ordovician units exposed in horses that are right-side up. Units stratigraphically above the Edinburg Formation exposed in horses are overturned including the Silurian Tuscarora Quartzite that makes up the east limb of the West Mountain syncline. The anticline on the footwall to the south of the southeastern jog of the fault becomes progressively overturned to the west. This structure may be the anticline that has been decapitated by the westward displacement of the North Mountain thrust sheet to the north.

\section{Discussion}

Boyer and Elliot [20] defined a horse as a pod of rock completely bound by two or more fault surfaces. Horses are derived from either the hanging wall or footwall of major thrusts and provide stratigraphic information from beneath a major thrust that cannot be obtained otherwise. Schultz [21] demonstrated the usefulness of the geology within horses in understanding the deformation of the Pulaski fault in southwestern Virginia. Here, rocks in the horses were the same age as those in the North Mountain fault zone; however, the Pulaski horses are complexly deformed with irregular fault contacts, the original stratigraphic sequences missing, and contain a predominance of inverted stratigraphy. By contrast, in the North Mountain fault zone, horses are not complexly deformed, original stratigraphic sequences are preserved, and there is a transition from right-side up to inverted sequences.

Analysis of bedding orientations within the North Mountain fault zone from detailed geologic mapping consistently parallel the strike of the Central Appalachians. Also, major folds on either side of the fault zone have consistent structural relationships (Figure 13). Horses within the fault zone document the deformation sequence. A key to the development of the fault zone as a fold-to-fault progression is the orientation of the horses along the leading edge. Anticlines preserved in horses have been identified along the 70 -mile $(113-\mathrm{km})$ stretch of the fault zone (Figure 1). The North Mountain fault zone in the Churchville quadrangle 

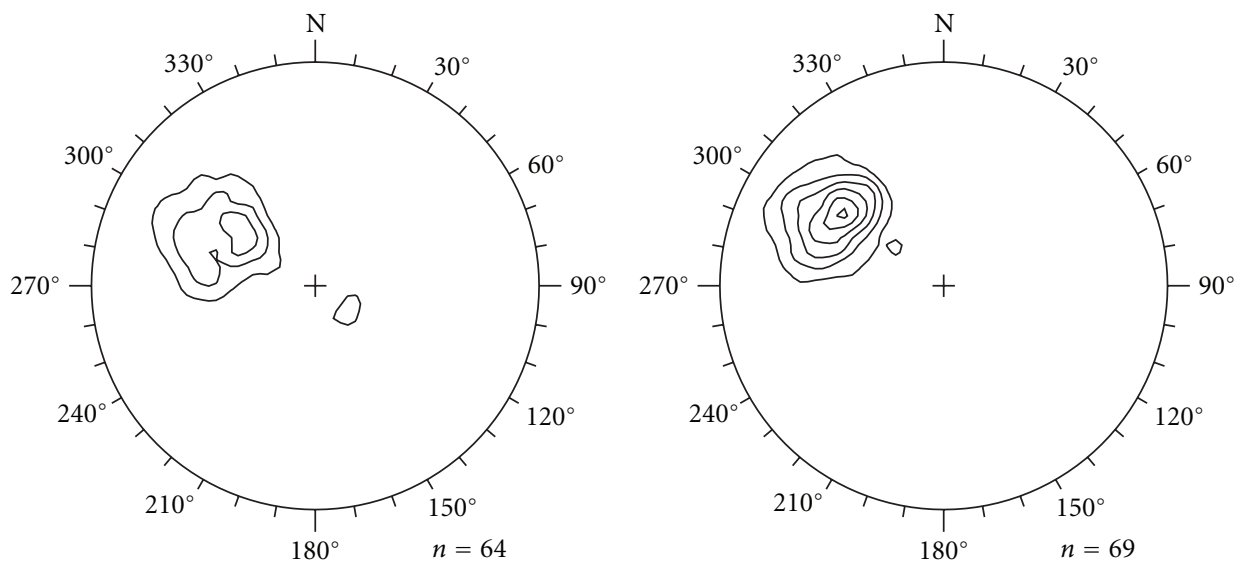

(a)

(b)

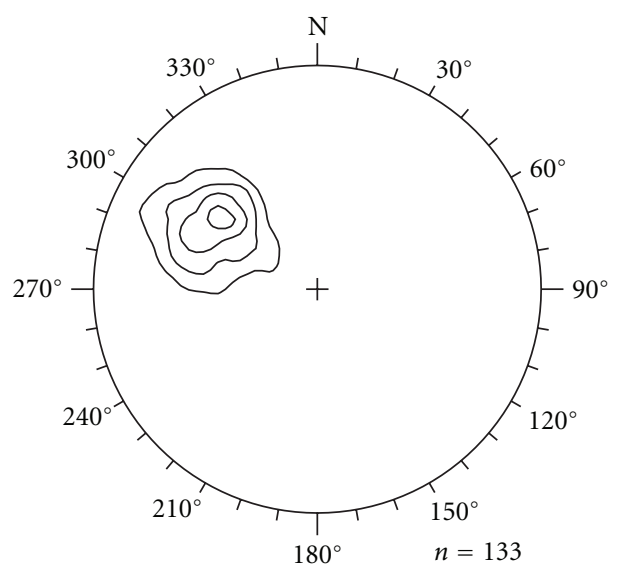

(c)

FIGURE 13: Lower-hemisphere equal-area stereographic plots of poles to bedding from detailed geologic mapping along the North Mountain fault zone. (a) Poles to bedding of upright Cambrian and Ordovician rocks. (b) Poles to bedding of overturned Ordovician to Devonian rocks. (c) Poles to bedding of all units in the North Mountain fault zone.

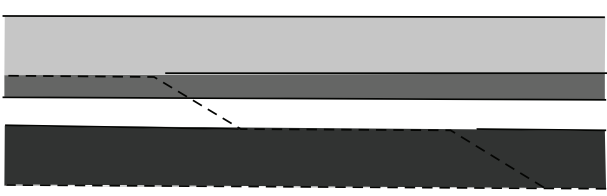

(a)

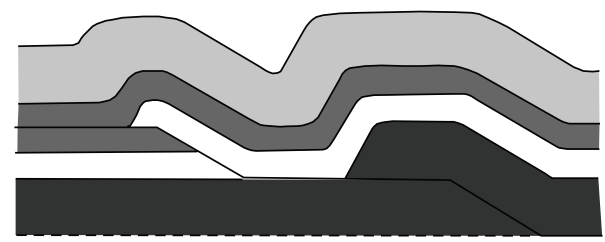

(b)

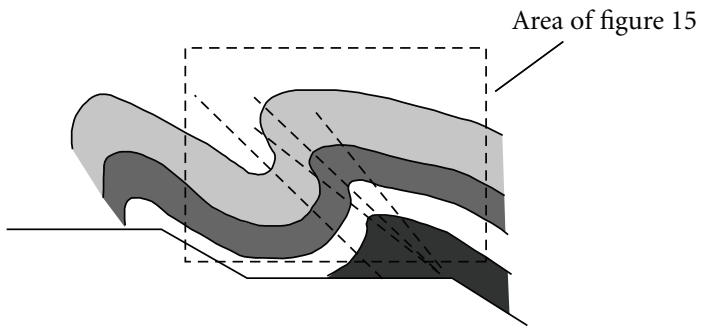

(c)

Figure 14: Conceptual model of detachment and folds showing progression of overturned folds and zones of shearing. (a) Initial compression develops ramps in the stratigraphic section. (b) Folds develop as shortening continues. (c) As folding continues, shear zones and faults develop along and oblique to the axial plane of the folds. 


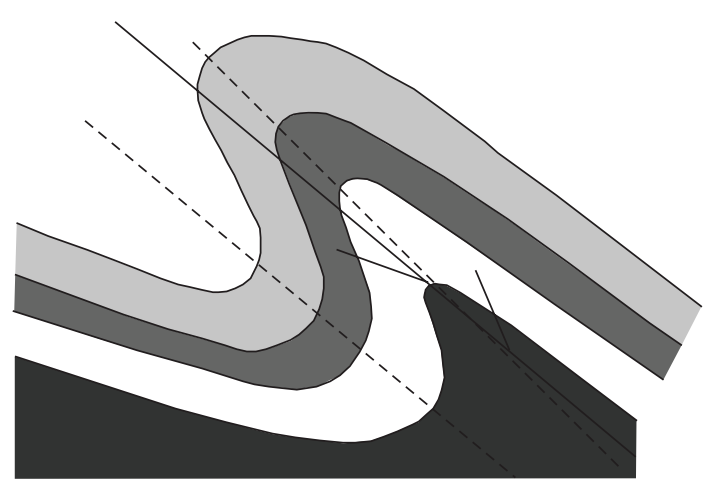

(a)

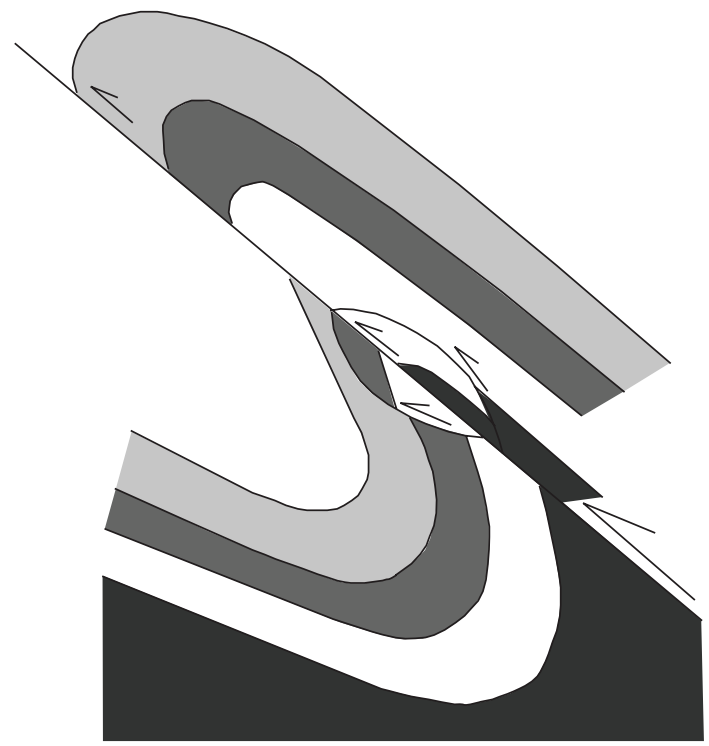

(c)

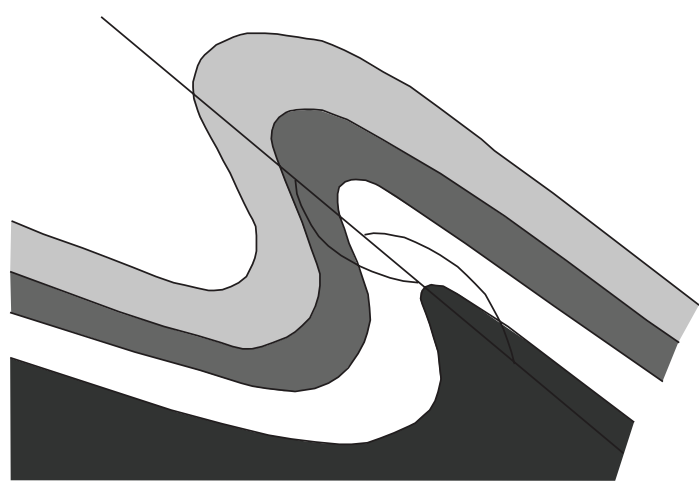

(b)

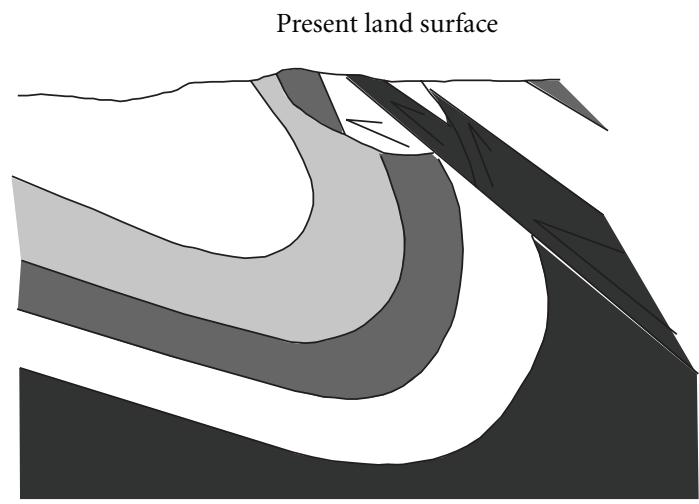

(d)

FIGURE 15: Conceptual model showing fold-to-fault progression and relationship of upright and overturned horses in the fault zone. (a) Overturned anticline-syncline pair with axial planes (dashed lines) and location of oblique and splay faults (heavy line). (b) Thrust faulting with origin of upright horse from upright limb of anticline. (c) Thrust faulting with origin of overturned horse from overturned limb of anticline. (d) Thrust fault zone showing current land surface and decapitated overturned anticline.

resides on a lateral ramp where the anticline was not overridden and consequently there are no horses (Figure 12). However, upright horses derived from this anticline where it was overridden occur in the Middletown quadrangle, Kipps Gap area, White Hall quadrangle, and the Singers Glen quadrangle as well as in many other areas along the fault zone. The transition from intact anticline to the North Mountain fault zone with horses occurs in the Churchville quadrangle. Also, this anticline documents the transition to the overturned western limb. Along the fault system to the north, rocks of the Edinburg Formation and higher in the stratigraphic section are overturned.

Willis [22] originally distinguished break thrusts that formed by thrusting the connecting limb of an anticlinesyncline pair, where the hanging wall anticline was overthrust and, thus, preserved the footwall syncline. Erosion has removed the hanging wall cutoff [23]; therefore, the major synclinal structure of the North Mountain thrust sheet, Massanutten synclinorium, is in thrust contact with the large regional overturned synclines such as the Back Creek, Mount Pleasant, Supin Lick, and West Mountain synclines (from north to south) (Figure 1).

Low-angle thrusts in the Appalachians are well documented, particularly in the Southern Appalachians [24]. However, the North Mountain fault zone in the Central Appalachians appears to be generally of moderate angle. For most of the length of the North Mountain fault zone, the fault is recognized topographically by Little North Mountain. The geometry of the various faults within the zone suggests fault dips of at least 30 to 40 degrees. This is determined by the elevation difference between the faults and the top of Little North Mountain, which gives a minimum angle for individual faults within the zone.

Suppe [25] recognized fault-propagation folds that form as stratigraphic layers are folded during propagation of a thrust through a sedimentary sequence and act similar to break thrusts. In other words, the fold forms as the fault propagates through the sedimentary sequence with 
progressive transfer of slip from the fault to the fold. Faultpropagation folds are the result of flexural bending of a layered sequence of rock in advance of the actual rupture and development of the fault plane. Though this model has been applied to thrust faults in the fold and thrust belt of the Appalachians, evidence from the North Mountain fault zone suggests that the folding occurred early in Alleghanian deformation and was not initiated by a propagating thrust fault (Figure 14).

Mitra [26] described faulted detachment folds that form in rock units with high competency contrasts and transition from folding to fault propagation as shortening increases. One characteristic of faulted detachment folds is that the fold-fault relationship shows a transition from folding to faulting with footwall synclines and decapitated anticlinal fold geometries [26]. The North Mountain fault zone occurs in rocks that have high competency contrasts between the Cambrian and Ordovician carbonates and the shaly units of the upper Middle Ordovician (Figure 3). This change in competency occurs in a transition in the Chambersburg/Edinburg Formation where dominant limestone and dolostone lithologies give way to calcareous shale and shaly limestone, and subsequently transitions into shale of the Martinsburg Formation, which is considered a detachment zone in the Central Appalachians [5]. Note that the change from right-side up to overturned horses in the North Mountain fault zone occurs in the transition from competent to less competent Middle Ordovician units.

Erslev [27] and Erslev and Mayborn [28] proposed trishear fault propagation through folds where the deformation zone is bounded by the axial planes of anticlinal hinges and the corresponding synclinal hinges. In this model, shear is distributed from the tip of the fault to a widening zone on the limb of steep and overturned beds. This distribution of shear may be the origin of subsidiary faults that led to the development of horses within the North Mountain fault zone.

\section{Conclusions}

Detailed examination of horses in the North Mountain fault zone document a fold-to-fault progression along the overturned southeast limb of a syncline to the northwest and the adjacent upright anticline to the southeast (Figure 15). Horses on the eastern part of the fault zone were derived from the upright limb or a hanging wall anticline. They structurally overlie overturned beds in the west part of the zone that were derived from the overturned limb of the subthrust syncline. Faulting occurred following the majority of the folding. The North Mountain fault plane is on a frontal ramp and is noncoaxial planar or oblique to an overturned anticline. This anticline is inferred since it is no longer exposed and the hanging wall cutoff has been removed by erosion. Evidence of this anticline exists in horses exposed along the present leading edge of the fault zone from central Virginia northward to the eastern panhandle of West Virginia. The moderate dip of the fault zone and consistent nature of the horses suggest that the North Mountain fault probably has less than 10 miles (16 kilometers) of horizontal displacement. Detailed geologic mapping is key to understanding complex structures in fold-andthrust belts. Understanding the relationships of structures, transitions, and competencies of rock units and right-side up to overturned nature of rocks in horses aids in determination of relative fold and fault timing in major thrust zones.

\section{Acknowledgments}

The author thanks Arthur P. Schultz and Robert C. Milici, U.S. Geological Survey, A.G. Leslie, British Geological Survey, and Robert Hatcher, University of Tennessee, for their suggestions and critical review of the paper. Also, the author appreciates the in-depth discussions and outcrop reviews on the structural geology of the Central Appalachians and North Mountain fault zone with C. Scott Southworth, David J. Weary, Jack B. Epstein, Robert C. McDowell, Daniel H. Doctor, E. William Decker, E. Brett Waller, and Kent D. Campbell.

\section{References}

[1] B. R. Kulander and S. L. Dean, "Structure and tectonics of central and southern Appalachian Valley and Ridge and Plateau provinces, West Virginia and Virginia," American Association of Petroleum Geologists Bulletin, vol. 70, no. 11, pp. 1674-1684, 1986.

[2] E. K. Rader and W. J. Perry Jr., "Reinterpretation of the geology of Brocks Gap, Rockingham County, Virginia," Virginia Division of Mineral Resources, Virginia Minerals, vol. 22, pp. 3745, 1976.

[3] B. R. Kulander and S. L. Dean, "The North Mountain-Pulaski fault system and related thrust sheet structure," in Geometrics and Mechanisms of Thrusting, with Special Reference to the Appalachians, G. Mitra and S. Wojtal, Eds., vol. 222, pp. 107118, Geological Society of America, 1988.

[4] S. L. Dean, B. R. Kulander, and P. Lessing, "The structural geometry and evolution of foreland thrust systems, northern Virginia: Alternative interpretation and reply," Geological Society of America Bulletin, vol. 102, pp. 1442-1445, 1990.

[5] M. A. Evans, "The structural geometry and evolution of foreland thrust systems, northern Virginia," Geological Society of America Bulletin, vol. 101, no. 3, pp. 339-354, 1989.

[6] A. W. Giles, "Geology of Little North Mountain in northern Virginia and West Virginia," Journal of Geology, vol. 35, pp. 32-57, 1927.

[7] C. Butts and R.S. Edmundson, "Geology of little North Mountain in contributions to Virginia geology-part II," Virginia Division of Mineral Resources Bulletin, vol. 51, pp. 163-179, 1939.

[8] C. Butts and R. S. Edmundson, "Geology and mineral resources of Frederick County," Virginia Division of Mineral Resources Bulletin, vol. 80, 142 pages, 1966.

[9] S. L. Dean, B. R. Kulander, and P. Lessing, "Geology of the Hedgesville, Keedysville, Shepherdstown, and Williamsport quadrangles, Berkeley and Jefferson Counties," West Virginia Geological Economic Survey Map-WV31, scale 1:24,000, 1987.

[10] D. H. Doctor, R. C. Orndorff, R. A. Parker, D. J. Weary, and J. E. Repetski, "Geologic map of the White Hall quadrangle, Frederick County, Virginia and Berkeley County," West 
Virginia. U.S. Geological Survey Open-file Report 2010-1265, scale 1:24,000, 2010.

[11] E. K. Rader, R. C. McDowell, T. M. Gathright III, and R. C. Orndorff, "Geologic map of Clarke, Frederick, Page, Shenandoah, and Warren Counties, Virginia," Lord Fairfax Planning District. Virginia Division of Mineral Resources Publication 143, scale 1:100,000, 1996.

[12] R. C. Orndorff and J. B. Epstein, "A structural and stratigraphic excursion through the Shenandoah Valley, Virginia," U.S. Geological Survey Open-file Report 94-573, 1994.

[13] R. C. Orndorff, J. B. Epstein, and R. C. McDowell, "Geologic map of the Middletown quadrangle, Frederick, Shenandoah, and Warren Counties, Virginia," U.S. Geological Survey Geologic Quadrangle Map GQ-1803, scale 1:24,000, 1999.

[14] J. B. Epstein, R. C. Orndorff, and E. K. Rader, "Middle Ordovician Stickley Run Member (new name) of the Martinsburg Formation, Shenandoah Valley, northern Virginia," US Geological Survey Bulletin, vol. 2135, pp. 1-13, 1995.

[15] R. C. McDowell, "Preliminary geologic map of the Mountain Falls quadrangle, Frederick and Shenandoah Counties, Virginia, and Hampshire County, West Virginia," U.S. Geological Survey Open-file Report 95-620, scale 1:24,000, 1995.

[16] W. R. Brent, "Geology and mineral resources of Rockingham County," Virginia Division of Mineral Resources Bulletin, vol. 76, p. 174, 1960.

[17] R. C. Orndorff, "Geologic map of the Muddy Creek drainage basin, Singers Glen quadrangle, Rockingham County, Virginia," U.S. Geological Survey Open-file Report 95-629, scale 1:24,000, 1995.

[18] M. J. Bartholomew, "Structural evolution of the Pulaski thrust system, southwestern Virginia," Geological Society of America Bulletin, vol. 99, pp. 491-510, 1987.

[19] E. K. Rader, "Geology of the Staunton, Churchville, Greenville, and Stuarts Draft quadrangles, Virginia," Virginia Division of Mineral Resources Report of Investigations 12, scale 1:24,000, 1967.

[20] S. E. Boyer and D. Elliott, "Thrust systems.," American Association of Petroleum Geologists Bulletin, vol. 66, no. 9, pp. 11961230, 1982.

[21] A. P. Schultz, "Horses in fensters of the Pulaski thrust sheet, southwestern Virginia: structure, kinematics, and implications for hydrocarbon potential of the Eastern Overthrust Belt," US Geological Survey Bulletin, vol. 1839, pp. A1-A13, 1988.

[22] B. Willis, "Mechanics of Appalachian structures," U.S. Geological Survey Annual Report 13, 1893.

[23] R. D. Hatcher Jr., W. A. Thomas, P. A. Geiser, A. W. Snoke, S. Mosher, and D. W. Wiltschko, "Alleghanian orogin," in The Appalachian-Ouachita orogen in the United States, R. D. Hatcher Jr., W. A. Thomas, and G. W. Viele, Eds., pp. 233-318, Geological Society of America, The Geology of North America F-2, 1989.

[24] L. D. Harris and R. C. Milici, "Characteristics of thin-skinned style of deformation in the Southern Appalachians, and potential hydrocarbon traps," U.S. Geological Survey Professional Paper, no. 1018, 1977.

[25] J. Suppe, Principles of Structural Geology, Prentice-Hall, Englewood, NJ, USA, 1985.

[26] S. Mitra, "Structural models of faulted detachment folds," American Association of Petroleum Geologists Bulletin, vol. 86, no. 9, pp. 1673-1694, 2002.

[27] E. A. Erslev, “Trishear fault-propagation folding," Geology, vol. 19, no. 6, pp. 617-620, 1991.
[28] E. A. Erslev and K. R. Mayborn, "Multiple geometries and modes of fault-propagation folding in the Canadian thrust belt," Journal of Structural Geology, vol. 19, no. 3-4, pp. 321335, 1997. 

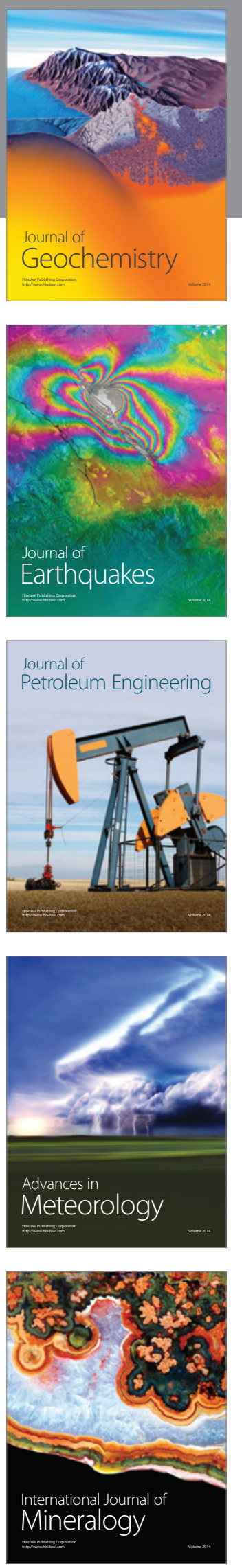
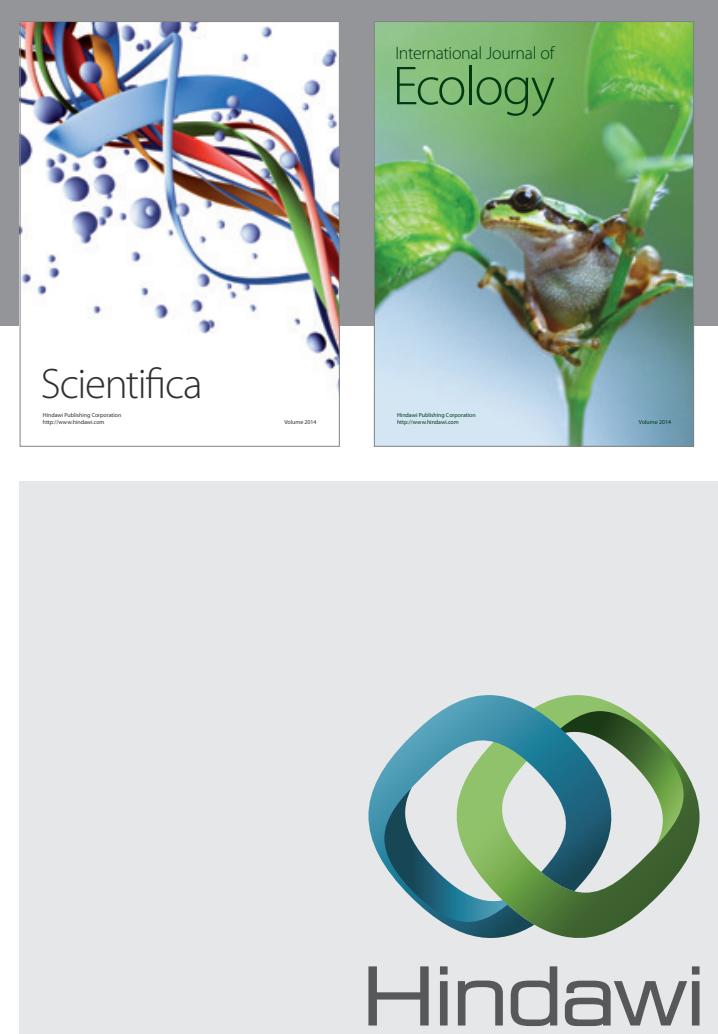

Submit your manuscripts at http://www.hindawi.com
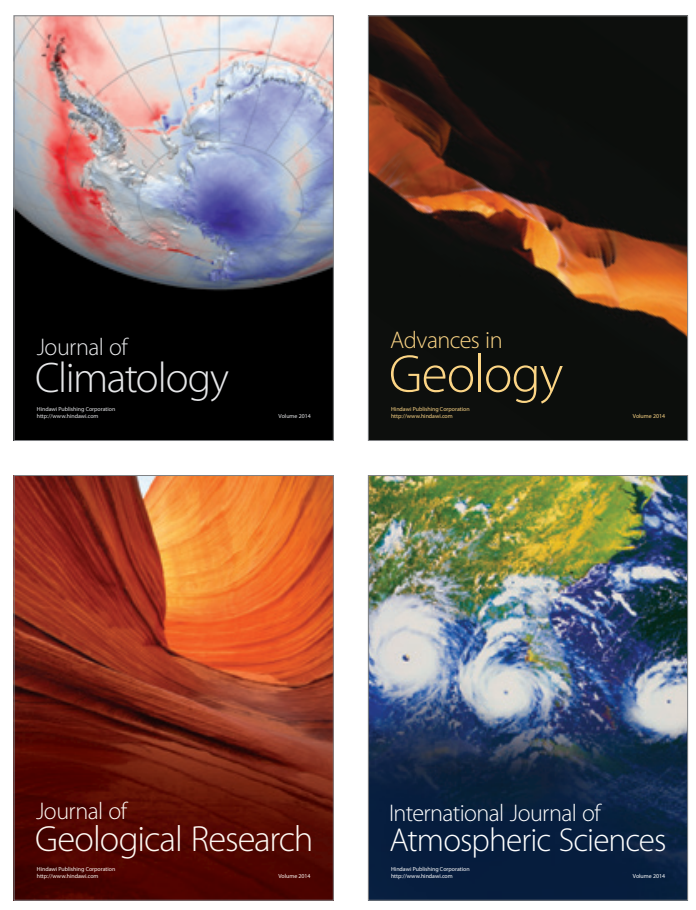
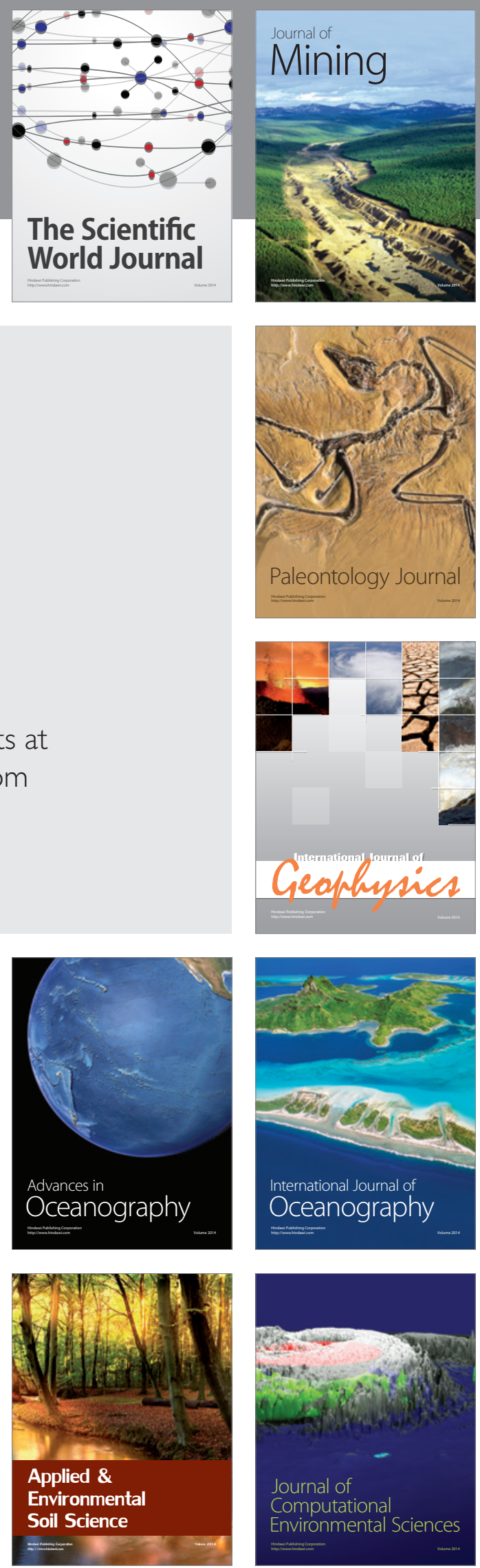